\title{
Gastric carcinosarcoma with rhabdomyosarcomatous differentiation: a case report and review
}

\author{
Masashi Fujiie ${ }^{1}$, Manabu Yamamoto ${ }^{1 *}$, Kenichi Taguchi ${ }^{2}$, Ayako Iwanaga ${ }^{1}$, Kippei Ohgaki $^{1}$, Akinori Egashira', \\ Kazuhito Minami ${ }^{1}$, Yasushi Toh ${ }^{1}$, Yoshinao Oda ${ }^{3}$ and Takeshi Okamura ${ }^{1}$
}

\begin{abstract}
We report an unusual case of gastric carcinosarcoma with rhabdomyosarcomatous and neudoendocrinal differentiation in a 71-year-old Japanese female. Gastric carcinosarcoma with rhabdomyosarcomatous and neuroendocrinal differentiation is a rare tumor. The tumor developed in the body of the stomach and was exophytic in appearance. By histochemical analysis, the tumor was shown a part of positive for desmin and myoglobin and a part of positive for synaphtophysin and vimentin.

We conclude that, though rare, gastric carcinosarcoma with rhabdomyosarcomatous and neuroendocrinal differentiation thus is reviewed in the English literatures.
\end{abstract}

Keywords: Gastric carcinosarcoma, Rhabdomyosarcomatous, Neuroendocrine

\section{Background}

Carcinosarcomas are rare, malignant, biphasic tumors. In the upper gastrointestinal tract, they are most frequently observed in the esophagus, while localization in the stomach has been less frequently reported [1-3]. We present a case of a 71-year-old female having gastric carcinosarcoma with rhabdomyosarcomatous and neudoendocrinal differentiation. Rhabdomyosarcomatous differentiation of the stomach is a rare neoplasm with only twelve cases previously reported [4-13].

We reviewed the scientific literature pertaining to gastric rhabdomyosarcoma and identified several distinctive clinical features of this type of tumor.

\section{Case presentation}

A 71-year-old Japanese female was admitted to the National Kyushu Cancer Center in April, 2012. Anorexia and vomiting were not observed; the CEA and CA19-9 levels were below the cutoff levels. Endoscopic studies revealed a Bormann II type lesion in the middle stomach (Fig. 1); rhabdomyosarcoma was confirmed on biopsy.

\footnotetext{
* Correspondence: yamamoto.m@nk-cc.go.jp

${ }^{1}$ Department of Gastroenterological Surgery, National Kyushu Cancer Center, 3-1-1 Notame, Minami-ku, Fukuoka 811-1395, Japan

Full list of author information is available at the end of the article
}

We performed a laparoscopic distal gastrectomy with D2 dissected lymph node on May, 2012. On macroscopic examination, a $2.0 \times 1.5 \mathrm{~cm}$ tumoral mass was identified in the body. The tumor invaded up until the subserosa, but no lymph node metastasis was found. As a result, the operation was considered to be curative. The patient was discharged on the 14th postoperative day. She was not admitted adjuvant chemotherapy by her offer. The patient has been doing well without any recurrence for 3 years.

Pathologically, the tumor was identified as carcinosarcoma with skeletal muscle and neuroendocrinal differentiation. In the submucosa, there was a proliferation of oval to polygonal cells with hyperchromatic nuclei, prominent nucleoli, and a small amount of eosinophilic cytoplasm, arranged in sheets and accompanied by thin fibro-vascular septa and prominent necrosis. Mitotic figures were frequently seen. Aggregates of histiocytes and granulation tissue were recognized in the surrounding gastric wall (Fig. 2a).

Immunohistochemical staining was performed using the ordinary avidine-biotin-peroxidase complex, and reaction products were visualized by benzidine reaction. The sections were slightly counterstained by hematoxylin. Immunohistochemically, the tumor cells 


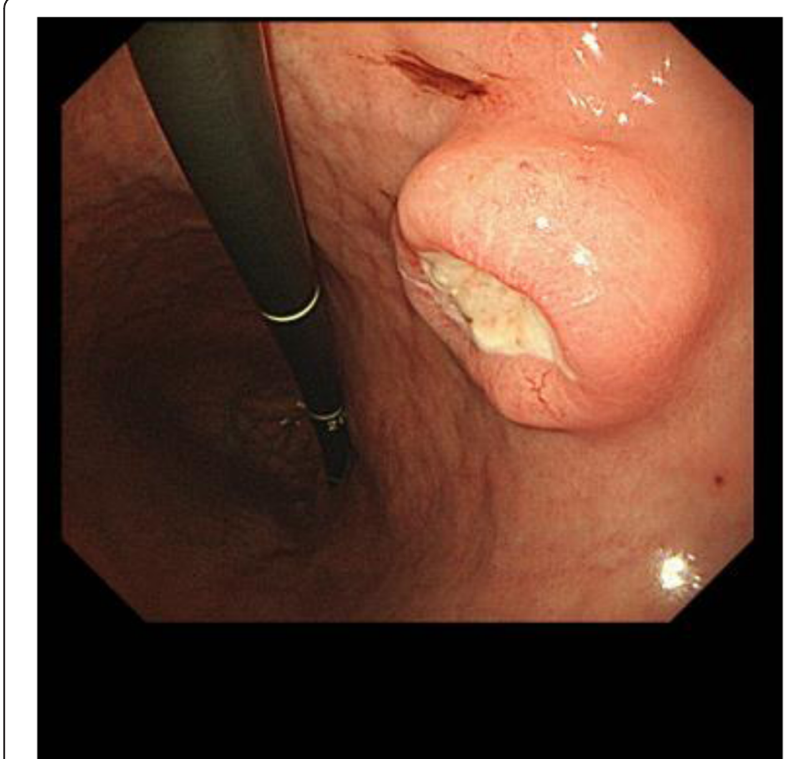

Fig. 1 Endoscopy showed an ulcerative lesion in the gastric body

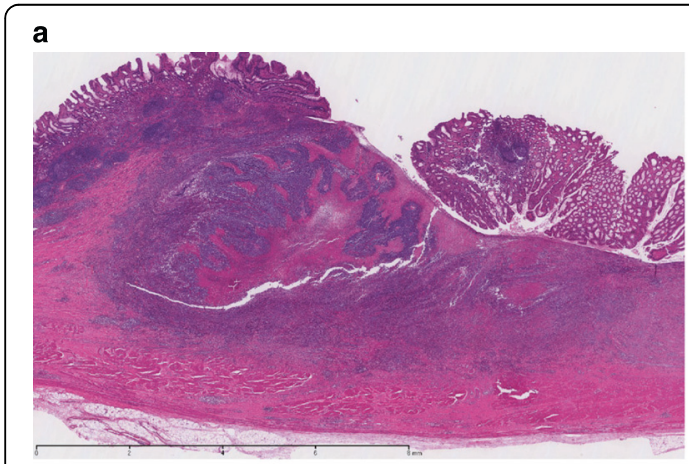

b

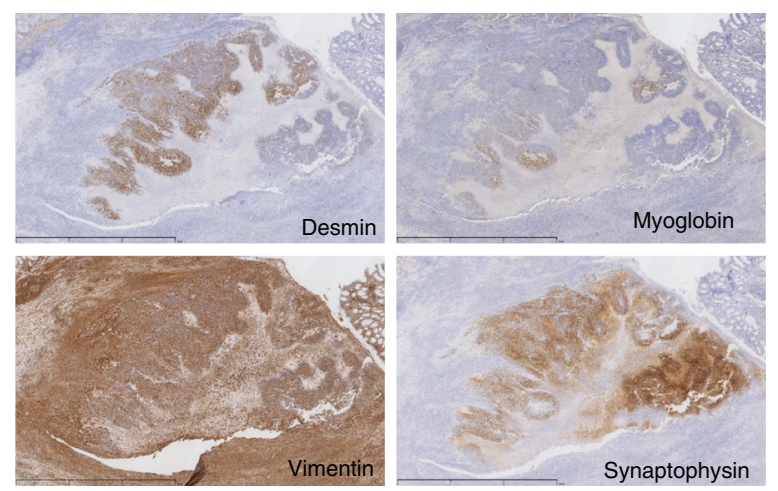

Fig. 2 a Hematoxylin-stained tumor specimen. b Immunohistochemical staining for desmin, myoglobin, vimentin, and synaptophysin was positive were positive for AE1/AE3, synaptophysin, desmin, and myogenin (Fig. 2b) but negative for CAM5.2, chromogranin A, S-100 protein, c-kit, and DOG1. PAX3/7-FKHR or EWS-WT1 fusion gene transcripts were not detected by RT-PCR $[14,15]$.

\section{Discussion}

In the Japanese and English scientific literature, about 60 cases of gastric carcinosarcoma have been reported. The most commonly reported carcinomatous component of this tumor is tubular or papillary carcinoma. The sarcomatous components have still not been adequately characterized in most of the reported cases. Distinct sarcomatous components showing heterologous differentiation such as leiomyosarcoma $[4,5,16-19]$, rhabdomyosarcoma $[4-13,20]$, osteosarcoma $[5,9,21]$, and chondrosarcoma [5, 22-24] have been reported. In our patient, not only rhabdomyoblastic differentiation but also neuroendocrine features were observed. This association of rhabdomyosarcomatous and neuroendocrinal differentiation has been described in only five cases of carcinosarcoma, affecting the pancreas [25], larynx [26], ileum [27], nanorectal junction [28], and stomach [12]. This case is the second report on gastric carcinosarcoma with rhabdomyosarcomatous and neuroendocrinal differentiation.

There is no indication that the gastric rhabdomyomatous component of gastric carcinosarcoma in our case or in other case reports represented a from some other site; indeed, metastases to the stomach by rhabdomyosarcomas are uncommon. De la Monte et al. reported that no instances of metastasis to the stomach in a review of 17 autopsies of 22 patients who died of embryonal and alveolar rhabdomyosarcoma at Johns Hopkins Hospital between 1929 and 1983 [29].

Gastric carcinosarcoma with rhabdomyosarcomatous differentiation has been reported in twelve cases (Table 1) [4-13]. In these twelve cases, no clinical feature has been associated with age, sex, or location. However, most cases showed a polypoid lesion, and in three of the 12 cases, it was recognized in the remnant stomach. There are cases which had poor prognosis. Actually, three of eight cases, which could confirm their survivals, were died within 1 year. The tendency of gastric rhabdomyosarcoma to metastasize to lymph node and lungs is in agreement with previous observations of rhabdomyosarcoma emerging at other sites [30].

The histogenesis of gastric carcinosarcoma remains controversial. Some authors have reported a bioclonal origin, which supports the collision tumor theory $[16,31]$. Others have proposed that these tumors are monoclonal and that the sarcomatous elements originate from a common stem cell that has the 
Table 1 Reported cases of gastric carcinosarcoma with rhabdomyosarcomatous differentiation

\begin{tabular}{|c|c|c|c|c|c|c|c|c|}
\hline \multirow[t]{2}{*}{ Author } & \multirow[t]{2}{*}{ Age/sex } & \multirow[t]{2}{*}{ Location } & \multirow[t]{2}{*}{ Size $(\mathrm{cm})$} & \multirow[t]{2}{*}{ Gross feature } & \multicolumn{2}{|c|}{ Depth of invasion } & \multirow{2}{*}{$\begin{array}{l}\text { Other specified } \\
\text { histology }\end{array}$} & \multirow[t]{2}{*}{ Outcome } \\
\hline & & & & & carcinoma & sarcoma & & \\
\hline Stout (1953) [8] & & & & & Submucosa & & & \\
\hline Stout (1953) [8] & & & & & Submucosa & & & \\
\hline Kyogoku (1960) [4] & $49 / M$ & & & & & & Leiomyosarcoma Fibrosarcoma & Dead, 36 mon \\
\hline Matsukuma (1977) [9] & $74 / \mathrm{M}$ & Remnant S & $15 \times 11$ & Polypoid & Serosa & Muscularis propria & Osteosarcoma Fibrosarcoma & Dead, 5 mon (Liver meta) \\
\hline Machida (1981) [7] & $39 / F$ & Cardia & $7.0 \times 6.0$ & Polypoid & Submucosa & Submucosa & Chondrosarcoma Leiomyosarcoma & Dead, 5 mon \\
\hline Fox (1990) [10] & $68 / F$ & Body & $15 \times 10$ & Polypoid & Mucosa & & & Dead, 26 mon \\
\hline Sugai (1991) [11] & $78 / \mathrm{M}$ & Pylorus & $9.0 \times 7.0$ & Polypoid & Serosa & & Spindle cell sarcoma & Dead, 5 mon \\
\hline Melato (1993) [5] & 73/M & Remnant S & $7.0 \times 5.5$ & Polypoid & Serosa & Serosa & Fibrosarcoma Chondrosarcoma & \\
\hline Nakayama(1997) [6] & $69 / M$ & Remnant S & $20 \times 18$ & Polypoid & & & Osteoblastic & Autopsy (Pheumonia) \\
\hline Tsuneyama(1999) [12] & $63 / \mathrm{M}$ & Pylorus & $7.0 \times 6.5$ & Polypoid & Subserosa & & Neuroendocrine tumor & Alive 10 mon \\
\hline Sato Y (2001) [13] & $67 / F$ & Fundus & $8.0 \times 7.0$ & Polypoid & & & Adenosquamous ca & Alive 11 mon \\
\hline Surg Case report 2016 (In press) & $71 / F$ & Body & $2.0 \times 1.5$ & Polypoid & Subserosa & Subserosa & Neuroendocrine tumor & Alive, 36 mon \\
\hline
\end{tabular}


ability to undergo both epithelial and mesenchymal differentiation [7, 32]. In our patient, there were occasional transitions between carcinomatous and sarcomatous components, and the immunohistochemical detection of stem in sarcomatous cells may suggest the sarcomatous differentiation of adenocarcinoma. During transdifferentiation, the occurrence of stem cells with multi-differentiation ability is capable to explain the variety of cell types observed in the present tumor.

Our experience with the present case emphasizes that gastric carcinosarcoma with rhabdomyosarcomatous differentiation exhibits aggressive behavior, the tumor, however, is extremely rare.

\section{Conclusions}

This report described a very rare case of gastric carcinosarcoma with rhabdomyosarcomatous lesions. This case has survived without tumor recurrence, though most cases of gastric carcinosarcoma with rhabdomyosarcomatous were poor prognosis.

\section{Consent for publication}

Patient consent for publication of images has been given in writing.

\section{Competing interests}

The authors declare that they have no competing interests.

\section{Authors' contributions}

$M F$ and MY contributed to writing the manuscript. YT, YO and TO supervised the study. $\mathrm{KT}$ and $\mathrm{YO}$ supported the pathological findings. Al, KO, AE and KM served as attending physicians of the presented patients. All authors read and approved the final manuscript.

\section{Author details}

'Department of Gastroenterological Surgery, National Kyushu Cancer Center, 3-1-1 Notame, Minami-ku, Fukuoka 811-1395, Japan. ${ }^{2}$ Department of Pathology, National Kyushu Cancer Center, 3-1-1 Notame, Minami-ku, Fukuoka 811-1395, Japan. ${ }^{3}$ Department of Pathology II, Kyushu University, 3-1-1 Maedashi, Higashi-ku, Fukuoka 812-8582, Japan.

Received: 3 March 2016 Accepted: 21 May 2016

Published online: 02 June 2016

\section{References}

1. Kanamoto A, Nakanishi Y, Ochiai A, Shimoda T, Yamaguchi H, Tachimori Y, et al. A case of small polypoid esophageal carcinoma with multidirectional differentiation, including neuroendocrine, squamous, ciliated glandular, and sarcomatous components. Arch Pathol Lab Med. 2000;124:1685-7.

2. Yamazaki K. A gastric carcinosarcoma with neuroendocrine cell differentiation and undifferentiated spindle-shaped sarcoma component possibly progressing from the conventional tubular adenocarcinoma; an immunohisto-chemical and ultrastructural study. Virchows Arch. 2003:442:77-81

3. Insabato L, Di Vizio D, Ciancia G, Oettinato G, Tornillo L, Terracciano L. Malignant gastrointestinal leiomyosarcoma and gastrointestinal stromal tumor with prominent osteoclast-like giant cells. Arch Pathol Lab Med. 2004; 128:440-3

4. Kyogoku M, Okukubo T, Aoki S. An autopsy case of carcinosarcoma which originated in the stomach. Gann. 1960;51:278-9.

5. Melato M, Bucconi S, Grillo BP, Angelucci P, Stefano PD, Natolic C. Carcinosarcoma and separate neuroendocrine malignant tumor of a malignancy promoter, the gastric stump. Anticancer Res. 1993;13:2485-8.
6. Nakayama Y, Murayama H, Iwasaki H, Iwanaga S, Kikuchi M, Ikeda S, et al. Gastric carcinosarcoma (sarcomatoid carcinoma) with rhabdomyoblastic and osteroblastic differentiation. Pathl Int. 1997;47:557-63.

7. Machida T, Takahashi M, Takeda T, Nakamura K. A carcinosarcoma of the stomach. Gan No Rinsho. 1981;27:1763-8.

8. Stout AP. Tumors of the stomach. In: Ackerman LV, Lattes R, editors. Atlas of tumor pathology, section 6, fascicle 21. Washington DC: Armed Forces Institute of Pathology; 1953. p. 98-9.

9. Matsukuma S, Wada R, Hase K, Sakai Y, Ogata S, Kuwabara N. Gastric stump carcinosarcoma with rhabdomyosarcomatous differentiation. Pathol Int. 1997:47:73-7.

10. Fox KR, Moussa SM, Mitre RJ, Zidar BL, Raves JJ. Clonical and pathology features of primary gastric rhabdomyosarcoma. Cancer. 1990;66:772-8.

11. Sugai A, Takayama K, Sasaki K, Kato R, Sasau S, Fujisawa H, et al. A carcinosarcoma of the stomach. Gan No Rinsho. 1991;37:777-83.

12. Tsuneyama K, Sasaki M, Sabit A, Yokoi K, Arano Y, Imai T, et al. A case of gastric carcinosarcoma with rhabdomyosarcomatous and neuroendocrinal differentiation. Pathology. 1999;195:93-7.

13. Sato Y, Shimozono T, Kawano S, Toyoda K, Onoe K, Asada Y, et al. Gastric carcinosarcoma, coexistence of adenosquamous carcinoma and rhabdomyosarcoma: a case report. Histopathology. 2001;39:540-7.

14. Sorensen PH, Lynch JC, Qualman SJ, Tirabosco R, Lim JF, Maurer HM, et al. PAX3-FKHR and PAX7-FKHR gene fusions are prognostic indicators in alveolar rhabdomyosarcoma: a report from the child's oncology group. J Clin Oncol. 2002;20:2672-9.

15. Lee SB, Kolquist KA, Nichols K, Englert C, Maheswaran S, Ladanyi M, et al. The EWS-WT1 translocation product induces PDGFA in desmoplastic small round-cell tumour. Nat Genet. 1997;17:309-13.

16. Dundas SA, Slater DN, Wagner BE, Mills PA. Gastric adenocarcinoleiomyosarcoma: a light electron microscopic and immunohistochemical study. Histopathology. 1988;13:347-50.

17. Kawabata Y, Nakai T, Ooba K, Okumura T, Matsuura Y, Miyazaki Y, et al. A case report of carcinosarcoma of the stomach. Nippon Shoukaibyo Gakkai Zasshi. 1993;26:2180-93 (in Japanese with English abstract).

18. Miyauchi K, Takano Y, Ohshima Y, Shimizu M, Watanabe T, Nishi Y, et al. A case of carcinosarcoma of the stomach. Nippon Syokakibyo Gakkai Zasshi. 1994:91:75-9 (in Japanese with English abstract).

19. Tanimura H, Furuta M. Carcinosarcomas: current perspectives and an historical review of nosological concepts. Semin Diagn Pathol. 1993;10:118-27.

20. Pinto JA, Gonzalez-Alfonso JE, Gonzalez L, Gonzalez L, Stevenson N, et al. Well differentiated gastric adenocarcinoma with rhabdoid areas: a case report with immunohistochemical analysis. Pathol Res Pract. 1997;193:801-8.

21. Ayral X, Cornud F, Favriel JM, Bocquet L, Debray C. Carcinosarcoma of stomach: report of a case and review of the literature. Gastroentrol Clin Biol. 1980:4:362-7.

22. Cho KJ, Myong NH, Choi DW, Jang JJ. Carcinosarcoma of stomach: a case report with light microscopic study. APMIS. 1990;98:991-5.

23. Minamoto T, Okada Y, Nakanishi I, Sawasaki K. So call gastric carcinosarcoma: a case of chandrosarcomatous dysdifferentiated in the metastatic foci. Gan No Rinsho. 1984;30:1321-6.

24. Seigel A, Freund U, Gal R. Carcinosarcoma of the stomach. Histopathology. 1988;13:350-3.

25. Ferreiro J, Lewin K, Herron R, Bhuta S. Malignant islet cell tumor with rhabdomyosarcomatous differentiation. Am J Surg Pathol. 1989;13:422-7.

26. Doglioni C, Ferlito A, Chimenti C, Viale G, Rosai J. Laryngeal carcinoma showing multidirectional epithelial neuroendocrine and sarcomatous differentiation. ORL J Otorhinolaryngol Relat Spec. 1990;52:316-26.

27. Dikman SH, Toker C. Enterblastoma complicating regional enteritis. APMIS. 1990;98:991-5.

28. Roncaroli F, Montironi R, Felicotti F, Losi L, Eusebi V. Sarcomatoid carcinoma of the anorectal junction with neuroendocrine and rhabdomyoblastic features. Am J Surg Pathol. 1995;19:217-23.

29. de la Montre SM, Hutchins GM, Moore GW. Metastatic behavior of rhabdomyosarcoma. Pathol Res Prat. 1986;181:148-52.

30. Enzinger FM, Weiss SW. Soft tissue tumors, vol. 49. 2nd ed. St. Louis: Mosby-year Book; 1988. p. 177-87.

31. Bansal M, Kaneko M, Gordon RE. Carcinosarcoma and separate carcinoid tumor of the stomach: a case report with light and electron microscopic studies. Cancer. 1982:50:1876-81.

32. Tomashino RM. Gastric carcinosarcoma: study of a case and its possible interpretation with reference to a new histogenetic theory. Arch Ital Anat Istol Pathol. 1970;43:364-85. 